\title{
Anthropometric Characteristics of Top-Class Brazilian Jiu Jitsu Athletes: Role of Fighting Style
}

\author{
Características Antropométricas en Atletas de Jiu Jitsu \\ Brasilero de Alto Nivel: Rol del Estilo de Lucha
}

\author{
Báez, E..,**; Franchini, E. ${ }^{\text {**** }}$ Ramírez-Campillo, R. ${ }^{* * * *}$; Cañas-Jamett, R. ${ }^{* *}$; \\ Herrera, T. ${ }^{* * * * * *}$; Burgos-Jara, C. ${ }^{* * * * * * *}$ \& Henríquez-Olguín, C. ${ }^{* * * * * * * *}$
}

BÁEZ, E.; FRANCHINI, E.; RAMÍREZ-CAMPILLO, R.; CAÑAS-JAMETT, R.; HERRERA, T.; BURGOS-JARA, C. \& HENRÍQUEZ-OLGUÍN, C. Anthropometric characteristics of top-class Brazilian Jiu Jitsu athletes: Role of fighting style. Int. J. Morphol., 32(3):1043-1050, 2014.

SUMMARY: Human performance efficiency and effectiveness in different sports depend to a large extent on the size, weight and proportion of the physique of the athlete. The aim of this study was to identify morphological characteristics of Brazilian Jiu-Jitsu (BJJ) athletes. The sample consisted of 25 highly trained male athletes who were classified according to their fighting style; guard fighter (GF) vs. pass fighter (PF). The athletes were assessed for somatotype, body composition and proportionality. For the whole group of athletes the somatotype was $2.23 \pm 0.68,6.33 \pm 1.14$, and $1.75 \pm 0.87$ for endomorph, mesomorph and ectomorph components, respectively. Muscle and adipose tissue percentages were $52.34 \pm 2.15 \%$ and $19.30 \pm 2.51 \%$, respectively. PF were significantly more mesomorph (p< $0.05)$ and less ectomorph ( $\mathrm{p}<0.05)$ than GF. Also, PF had significantly higher phantom $\mathrm{Z}$ score for bone mass vs. GF (0.51 \pm 0.57 vs. $0.01 \pm 0.54 ; \mathrm{p}<0.05)$, and significantly lower muscle mass- bone mass ratio (4.55 $\pm 0.31 \mathrm{vs.} 4.77 \pm 0.56$; $\mathrm{p}<0.05)$, height $(1.71 \pm 0.06$ vs. $1.77 \pm 0.07 ; \mathrm{p}<0.05)$ and height weight ratio $(40.58 \pm 1.11 \mathrm{vs.} 41.84 \pm 1.22)$. Our results show that morphological characteristics are related to different fighting styles in BJJ athletes.

KEY WORDS: Anthropometric characteristics; Somatotype; Jiu Jitsu; Fighting style.

\section{INTRODUCTION}

Kinanthropometry is defined as the study of human size, shape, proportion, composition, maturation, and gross function, in order to understand growth, exercise, performance, and nutrition (Tsang et al., 2000). In combat sports, the athletes anthropometry can affect their performance (Iide et al., 2008) and some anthropometric variables allow us to identify athletes of different performance levels (Vidal Andreato et al., 2011; Franchini et al., 2005; Gualdi-Russo \& Graziani, 1993). Additionally, combat sports athletes are classified according to their body mass, and a better understanding of their body fat percentage can help in the decision to change or not their weight category (Artioli et al., 2010; Franchini et al., 2012; Santos et al., 2012).
Brazilian Jiu-Jitsu (BJJ) is a grappling combat sport that has gained a lot of popularity throughout the world. The objective of this sport is to dominate the opponent by means of specific techniques that are based in positions, joint-locks and strangles, which result in scores or in the opponent's submission (Vidal Andreato et al., 2012a, 2012b; Boscolo Del Vecchio et al., 2007). In BJJ, there are two main styles of fighters: "pass fighters" (PF) and "guard fighters" (GF). While PF try to break the guard, getting scores or advantage positions, GF defend the guard and attack from there.

Recently, the physiological demands (Vidal Andreato et al., 2012a, 2012b; Moreira et al., 2012; Santos et al.) and

Departamento de Deportes y Recreación, Facultad de Ciencias de la Actividad Física, Universidad de Playa Ancha, Chile.

** Laboratorio de Fisiología, Departamento de Ciencias Biológicas, Facultad de Ciencias Biológicas, Universidad Andrés Bello, Chile.

*** Grupo de Investigación en Artes Marciales y Deportes de Combate, Departamento de Deportes, Escuela de Educación Física y Deporte, Universidad de São Paulo, Brasil.

**** Departamento Ciencias de la Actividad Física, Universidad de Los Lagos, Chile.

******* Programa de Ciencias de la Actividad Física, Facultad de Ciencias Médicas, Universidad de Santiago, Chile.

****** Laboratorio de Ciencias del Ejercicio, Centro de Medicina Deportiva MEDS, Chile. 
adaptations (Henríquez et al., 2013) to competition and training in BJJ had been reported. However, the kinanthropometric characteristics of elite BJJ athletes lacks in scientific literature (Vidal Andreato et al., 2011, 2012a) and the morphological characteristics can differ among fighters with different combat styles (Iwai et al., 2008).

To the best of the author's knowledge, studies that had examined anthropometrical characteristics of BJJ fighters had used relative small number of athletes, and studies regarding kinanthropometric characteristics of BJJ athletes of different fighting styles have not been published. This information can offer the possibility of optimizing sport selection to athletes and coaches. Thus, the aim of this work was to analyze body composition, somatotype and proportionality in BJJ athletes and also to analyze these variables in BJJ athletes of different fighting styles (i.e. PF vs. GF).

\section{SUBJECT AND METHOD}

Sample. Consisted of 25 highly trained BJJ athletes who competed at the 2012 men World BJJ Championship in the male adult category, with purple, brown and black belt degrees (three highest degrees). Athletes were divided in two groups accordingly: GF and PF according to their description of the most used combat strategy during combats, and this information was confirmed by visual inspection during official matches during the World BJJ Championship 2012. Similar weight categories distributions were determined in the groups. Athletes agreed voluntarily to be part of the study. An institutional Review Board approval for our study was obtained, and all athletes were carefully informed about the experiment procedures and about the possible risks and benefits associated with their participation in the study, a properly signed informed consent document was obtained according to the law before any of the tests were performed. The local ethics committee approved the study. We complied with the human experimentation policy statement guidelines of the American College of Sport Medicine, and in accordance with the Declaration of Helsinki. All athletes were healthy, with no history of cardiovascular or respiratory diseases, and with no caffeine, cigarette, alcohol or drug consumption 24 hours before the evaluation Athletes reported a training frequency of $6 \pm 1.2$ days/week and $3 \pm 2.2$ hours each day.

Data collection and analysis. Body mass (kg) was measured with electronic scale (Tanita ${ }^{\circledR}$ TBF 401A, Tanita, Japan), height $(\mathrm{m})$ and sitting height $(\mathrm{m})$ with wall-mounted stadiometers and $50 \mathrm{~cm}$ high wooden boxes. Body mass index (BMI) and height/weight ratio (HWR) were determined. Large bone breadth $(\mathrm{cm})$ with HP 50 sliding-branch callipers
(Callipers Health \& Performance ${ }$, Chile), small bone breadth (cm) with Campbell 10 sliding-branch callipers (Callipers Health \& Performance ${ }^{\circ}$, Chile), head, limb, and torso girths (cm) with metallic non-extensible tapes (Lufkin ${ }^{\circledR}$ W606PM, Cooper Tools, Mexico), and skinfolds thicknesses (mm) with Slim guide callipers (Rosscraft@, Creative Health Products, USA), were measured.

Body composition was calculated using the five-way fractionation model, partitioning the body into anatomically defined adipose, muscle, residual, bone, and skin tissue masses (Kerr, 1988). The five-way fractionation model has several advantages over traditional two-component hydrodensitometry-based models: (a) it provides information about components of lean body mass, muscle, and bone; (b) it is based on multiple-regression equations, thereby avoiding the sample-specificity problem; (c) it is validated through cadaver dissection analysis; (d) the error in body mass prediction from the five-way fractionation method can be seen as an element of internal validity if the predicted structured body mass falls within $5 \%$ of measured body mass (Kerr, 1988, Ross, 1991) The fractional masses of the fiveway fractionation method were estimated from direct anthropometric measures, added to yield a "structured mass," and from which relative tissue percentages were calculated. The difference between "structured mass" and actual body mass, expressed in absolute terms and as a percentage of body mass, provided information on the error of the model. This difference was then proportionally adjusted to each tissue to yield a sum of individual tissue masses that was equal to the actual body mass.

The proportionality of body mass fractionation was determined with the Phantom Z-score stratagem (Ross \& Marfell-Jones, 1991). Carter and Heath equations were used to calculate the anthropometric somatotype.

Statistics. The Somatotype Calculation and Analysis Software ${ }^{\circ}$ version 1.1 (San Diego, CA, USA) were used to plot the somatotype and calculate the frequencies in somatotype categories. Descriptive statistical analyses were carried out using GraphPad Prism 5.0® (Graphpad Software, San Diego, CA, USA). The special somatotype analysis of variance method (SANOVA) was used to compare the three-dimensional somatotype distributions and the mean somatotype according to the fighting style. Comparisons of means were made by using the non-paired t-student test. To evaluate the magnitude of difference, the Cohen's effect size was calculated to evaluate the magnitude of difference Threshold values to effect size were: $<0.2$ (small), $>0.2$ to $<0.8$ (moderate) and $>0.8$ (large). Data in the text are presented as the mean \pm standard deviation (SD). Alpha level was set at $\mathrm{p}<0.05$. 


\section{RESULTS}

No significant difference was found in age, body weight, or BMI between GF and PF groups. However, GF presented a significant higher height $(\mathrm{F}=4.85, \mathrm{p}=0.036$ and effect size $=0.711)$ and HWR $(F=6.85, p=0.015$ and effect size $=0.819)$ than PF athletes (Table I).

The whole group of BJJ athletes presented a balanced mesomorph somatotype (2.23-6.33-1.75, Table I). A graphical description of individual values of somatotype for the $\mathrm{PF}$ and GF is shown in Figure 1A. The $60 \%$ and $40 \%$ of PF were classified as endomorph-mesomorph and balanced mesomorph athletes, respectively (Fig. 1B). In the GF group 40\%, 20\%, and $40 \%$ were classified as endomorphs-mesomorphs, balanced mesomorphs, and ectomorphs-mesomorphs athletes, respectively (Fig. 1C). PF athletes exhibited a significant lower ectomorph value $(\mathrm{F}=6.38, \mathrm{p}=0.018$ and effect size $=0.799)$, and a significant higher mesomorph value $(\mathrm{F}=6.65, \mathrm{p}=0.016$ and effect size $=0.811)$ than GF (Table I).

In relation to proportionality, Table II shows that BJJ athletes present high upper body girths Phantom Z (arm relaxed $2.33 \pm 0.95$, arm flexed $2.45 \pm 1$, forearm $2.38 \pm 1.1$, and chest $1.54 \pm 0.88$ ). However, in the lower body girths the athletes show lower proportionality values (upper thigh $0.02 \pm 0.88$, mid- thigh $1.12 \pm 1.11$, and calf $0.02 \pm 1.05$ ). BJJ group is characterized by relatively low values of Z-scores

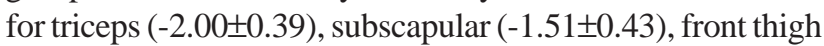
$(-2.34 \pm 0.28)$, and medial calf $(-2.31 \pm 0.41)$ skinfolds.

Significant differences were found between PF and GF in the proportionality's scores in forearm ( $3.03 \pm 0.98$ vs. $1.94 \pm 0.97$, respectively, $\mathrm{p}<0.05)$, chest $(2.0 \pm 0.7$ vs. $1.1 \pm 0.7$, respectively, $\mathrm{p}<0.05)$ and waist $(1.8 \pm 0.9$ vs. $0.9 \pm 1.0$, respectively, $\mathrm{p}<0.05$ ) girths (Table II). Table III shows that GF group exhibited a significant lower phantom Z-score of bone mass $(t=2.23 ; p=0.035$; effect size $=0.421)$.

No differences between structured body mass and real body mass was found using the five-way fractionation model. A very low prediction error was observed and no significant difference was found between structured body mass and actual body mass.

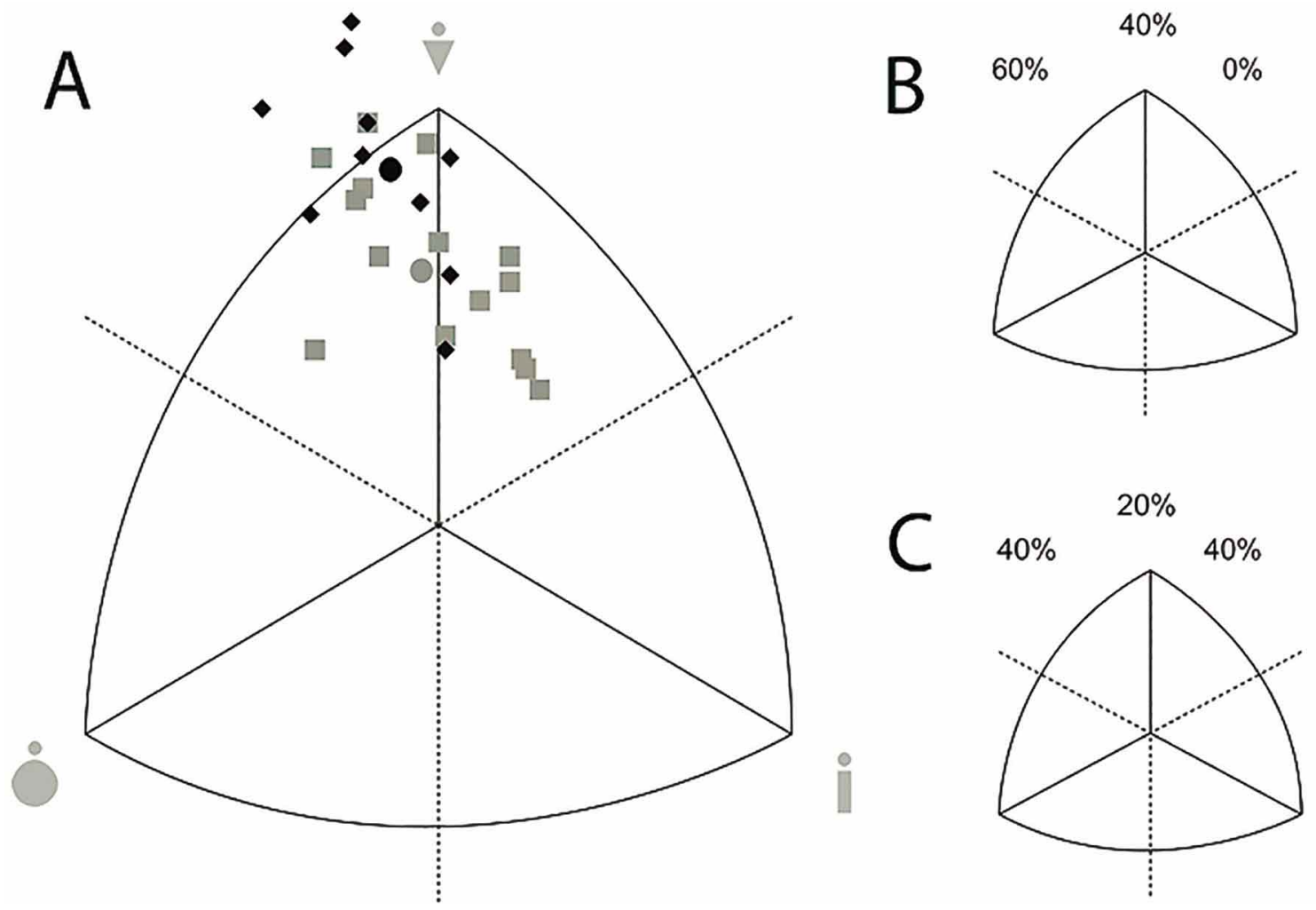

Fig. 1. (A) Somatoplot distribution of BJJ athletes according to fighting style. Grey squares: guard fighters. Black diamonds: pass fighters. The big black and gray circles represent the group mean for GF and PF, respectively. (B) Relative somatotype components distribution of PF athletes. (C) Relative somatotype components distribution of GF athletes. 
Table I. General and kinanthropometric descriptive characteristics of Brazilian Jiu-Jitsu athletes.

\begin{tabular}{lccc}
\hline & $\begin{array}{c}\text { Pass Fighter } \\
(\mathbf{n = 1 0})\end{array}$ & $\begin{array}{c}\text { Guard Fighter } \\
(\mathbf{n = 1 5 )}\end{array}$ & $\begin{array}{c}\text { All Subjects } \\
(\mathbf{n = 2 5})\end{array}$ \\
\hline Age (years) & $27.77 \pm 5.26$ & $25.33 \pm 5.74$ & $26.31 \pm 5.58$ \\
Height $(\mathrm{cm})$ & $170.80 \pm 6.00$ & $176.55 \pm 6.64^{*}$ & $174.25 \pm 6.89$ \\
Body weight $(\mathrm{kg})$ & $75.00 \pm 8.90$ & $75.94 \pm 11.89$ & $75.56 \pm 10.60$ \\
BMI & $25.52 \pm 2.20$ & $24.23 \pm 2.47$ & $24.80 \pm 2.35$ \\
HRW & $40.58 \pm 1.11$ & $41.84 \pm 1.22^{*}$ & $41.34 \pm 1.32$ \\
Endomorphy & $2.32 \pm 0.64$ & $2.17 \pm 0.72$ & $2.23 \pm 0.68$ \\
Mesomorphy & $6.98 \pm 1.19$ & $5.90 \pm 0.90^{*}$ & $6.33 \pm 1.14$ \\
Ectomorphy & $1.26 \pm 0.64$ & $2.07 \pm 0.87 *$ & $1.75 \pm 0.87$ \\
SAM & $1.27 \pm 0.65$ & $1.23 \pm 0.48$ & $1.24 \pm 0.54$ \\
\hline
\end{tabular}

BMI: body mass index; HWR: Height weight ratio; SAM: somatotype attitudinal mean. Data are expressed as mean \pm S.D., * denotes significant difference $(\mathrm{p}<0.05)$ versus Pass Fighter group, non-paired $t$ student test.

Table II. Proportionality values of Brazilian Jiu-Jitsu athletes.

\begin{tabular}{|c|c|c|c|c|}
\hline & & $\begin{array}{l}\text { Pass fighter } \\
(n=10)\end{array}$ & $\begin{array}{c}\text { Guard fighter } \\
(n=15)\end{array}$ & $\begin{array}{c}\text { All Athletes } \\
(n=25)\end{array}$ \\
\hline \multirow{6}{*}{$\begin{array}{l}\text { Skinfolds } \\
(\mathrm{mm})\end{array}$} & Triceps & $6.7 \pm 1.3$ & $6.5 \pm 2.1$ & $6.6 \pm 1.8$ \\
\hline & Subscapular & $10.0 \pm 1.9$ & $9.6 \pm 2.7$ & $9.7 \pm 2.4$ \\
\hline & Supraspinale & $6.8 \pm 2.9$ & $6.0 \pm 2.3$ & $6.3 \pm 2.6$ \\
\hline & Abdominal & $10.6 \pm 5.3$ & $9.5 \pm 6.0$ & $9.9 \pm 5.5$ \\
\hline & Front thigh & $7.3 \pm 2.0$ & $8.0 \pm 2.9$ & $7.7 \pm 2.5$ \\
\hline & Medial calf & $4.7 \pm 1.7$ & $5.8 \pm 2.9$ & $5.3 \pm 2.1$ \\
\hline \multirow{6}{*}{$\begin{array}{l}\text { Skinfolds } \\
\text { Phantom Z }\end{array}$} & Triceps & $-1.9 \pm 0.3$ & $-2.0 \pm 0.4$ & $-2.0 \pm 0.3$ \\
\hline & Subscapular & $-1.4 \pm 0.3$ & $-1.5 \pm 0.4$ & $-1.5 \pm 0.4$ \\
\hline & Supraspinale & $-1.9 \pm 0.6$ & $-2.1 \pm 0.4$ & $-2.0 \pm 0.5$ \\
\hline & Abdominal & $-1.9 \pm 0.6$ & $-2.0 \pm 0.7$ & $-2.0 \pm 0.6$ \\
\hline & Front thigh & $-2.3 \pm 0.2$ & $-2.3 \pm 0.3$ & $-2.3 \pm 0.2$ \\
\hline & Medial Calf & $-2.4 \pm 0.3$ & $-2.2 \pm 0.4$ & $-2.3 \pm 0.4$ \\
\hline \multirow{7}{*}{$\begin{array}{l}\text { Girths } \\
(\mathrm{cm})\end{array}$} & Arm, relaxed & $33.3 \pm 2.2$ & $32.8 \pm 2.5$ & $33.0 \pm 2.4$ \\
\hline & Arm, flexed & $36.2 \pm 2.4$ & $35.9 \pm 2.8$ & $36.0 \pm 2.6$ \\
\hline & Forearm & $29.5 \pm 1.6$ & $28.9 \pm 1.8$ & $29.1 \pm 1.7$ \\
\hline & Chest & $98.9 \pm 4.2$ & $97.5 \pm 5.9$ & $98.1 \pm 5.2$ \\
\hline & Waist (minimal) & $80.3 \pm 5.3$ & $79.0 \pm 6.1$ & $79.5 \pm 5.7$ \\
\hline & Upper thigh & $57.8 \pm 3.9$ & $56.9 \pm 5.1$ & $57.2 \pm 4.6$ \\
\hline & Calf (maximal & $36.5 \pm 2.6$ & $35.8 \pm 2.7$ & $36.1 \pm 2.6$ \\
\hline \multirow{7}{*}{$\begin{array}{l}\text { Girths } \\
\text { Phantom }\end{array}$} & Arm, relaxed & $2.7 \pm 0.9$ & $2.0 \pm 0.9$ & $2.3 \pm 0.9$ \\
\hline & Arm, flexed & $2.8 \pm 0.9$ & $2.2 \pm 0.9$ & $2.4 \pm 1.0$ \\
\hline & Forearm & $3.0 \pm 0.9$ & $1.9 \pm 0.9^{*}$ & $2.3 \pm 1.1$ \\
\hline & Chest & $2.0 \pm 0.7$ & $1.1 \pm 0.7 *$ & $1.5 \pm 0.8$ \\
\hline & Waist (minimal) & $1.8 \pm 0.9$ & $0.9 \pm 1.0^{*}$ & $1.3 \pm 1.0$ \\
\hline & Upper thigh & $0.4 \pm 0.7$ & $-0.2 \pm 0.8$ & $0.0 \pm 0.88$ \\
\hline & Calf (maximal) & $0.5 \pm 1.1$ & $-0.3 \pm 0.8^{*}$ & $0.0 \pm 1.0$ \\
\hline \multirow{5}{*}{$\begin{array}{l}\text { Breadths } \\
(\mathrm{cm})\end{array}$} & Biacromiale & $39.40 \pm 0.64$ & $39.47 \pm 2.03$ & $39.44 \pm 2.09$ \\
\hline & Transverse chest & $28.78 \pm 1.32$ & $27.95 \pm 1.82$ & $28.12 \pm 1.76$ \\
\hline & Bi-cristale & $27.33 \pm 2.31$ & $27.09 \pm 1.82$ & $27.18 \pm 1.98$ \\
\hline & Humerus & $7.34 \pm 0.38$ & $7.31 \pm 0.42$ & $7.32 \pm 0.40$ \\
\hline & Femur & $10.07 \pm 0.38$ & $9.89 \pm 0.47$ & $9.96 \pm 0.43$ \\
\hline \multirow{5}{*}{$\begin{array}{l}\text { Skinfolds } \\
\text { Phantom Z }\end{array}$} & Biacromiale & $0.64 \pm 1.00$ & $0.01 \pm 0.98$ & $0.26 \pm 1.01$ \\
\hline & Transverse chest & $0.20 \pm 0.71$ & $-0.57 \pm 0.77 *$ & $-0.26 \pm 0.82$ \\
\hline & Bi-cristale & $-0.93 \pm 1.02$ & $-1.57 \pm 0.68$ & $-1.31 \pm 0.87$ \\
\hline & Humerus & $2.39 \pm 1.07$ & $1.62 \pm 1.09$ & $1.93 \pm 1.13$ \\
\hline & Femur & $1.08 \pm 0.66$ & $0.04 \pm 0.78^{*}$ & $0.46 \pm 0.89$ \\
\hline
\end{tabular}

Data are expressed as mean \pm S.D., * denotes significant difference $(\mathrm{p}<0.05)$ versus PF group, t-student non-paired. 
Table III. Body composition indices in Brazilian Jiu-Jitsu athletes.

\begin{tabular}{|c|c|c|c|c|}
\hline & & $\begin{array}{c}\text { Pass fighter } \\
(\mathbf{n}=10)\end{array}$ & $\begin{array}{c}\text { Guard fighter } \\
(n=15)\end{array}$ & $\begin{array}{c}\text { All Athletes } \\
(\mathbf{n}=\mathbf{2 5})\end{array}$ \\
\hline \multirow[t]{3}{*}{ Adipose mass } & $(\%)$ & $18.4 \pm 2.5$ & $19.86 \pm 2.50 *$ & $19.30 \pm 2.5$ \\
\hline & $(\mathrm{kg})$ & $14.0 \pm 3.1$ & $15.09 \pm 3.6$ & $14.6 \pm 3.3$ \\
\hline & Phantom Z & $-2.0 \pm 0.4$ & $-1.90 \pm 0.5$ & $-1.9 \pm 0.4$ \\
\hline \multirow[t]{3}{*}{ Muscle mass } & $(\%)$ & $53.0 \pm 2.0$ & $51.88 \pm 2.2$ & $52.3 \pm 2.1$ \\
\hline & $(\mathrm{kg})$ & $40.0 \pm 4.4$ & $39.27 \pm 7.0$ & $39.5 \pm 5.8$ \\
\hline & Phantom Z & $3.4 \pm 0.8$ & $2.94 \pm 1.2$ & $3.1 \pm 1.1$ \\
\hline \multirow[t]{3}{*}{ Residual mass } & $(\%)$ & $11.8 \pm 0.6$ & $11.96 \pm 1.3$ & $11.8 \pm 1.1$ \\
\hline & $(\mathrm{kg})$ & $8.9 \pm 1.0$ & $9.01 \pm 1.5$ & $8.9 \pm 1.3$ \\
\hline & Phantom Z & $2.3 \pm 0.7$ & $2.14 \pm 1.1$ & $2.2 \pm 0.9$ \\
\hline \multirow[t]{3}{*}{ Bone mass } & $(\%)$ & $11.5 \pm 0.8$ & $10.99 \pm 1.0$ & $11.2 \pm 0.9$ \\
\hline & $(\mathrm{kg})$ & $8.7 \pm 1.0$ & $8.22 \pm 1.0$ & $8.4 \pm 1.0$ \\
\hline & Phantom Z & $0.5 \pm 0.5$ & $0.01 \pm 0.5^{*}$ & $0.2 \pm 0.5$ \\
\hline \multirow[t]{4}{*}{ Skin } & $(\%)$ & $5.1 \pm 0.2$ & $5.32 \pm 0.4$ & $5.2 \pm 0.3$ \\
\hline & $(\mathrm{kg})$ & $3.8 \pm 0.2$ & $3.97 \pm 0.3$ & $3.9 \pm 0.3$ \\
\hline & $\begin{array}{l}\text { Muscle mass }(\mathrm{kg}) \\
\text { bone mass }(\mathrm{kg}) \text { ratio }\end{array}$ & $4.5 \pm 0.3$ & $4.77 \pm 0.5^{*}$ & $4.7 \pm 0.4$ \\
\hline & $\begin{array}{l}\text { Adipose mass }(\mathrm{kg}) \\
\text { muscle mass }(\mathrm{kg}) \text { ratio }\end{array}$ & $0.35 \pm 0.06$ & $0.39 \pm 0.06$ & $0.38 \pm 0.06$ \\
\hline
\end{tabular}

Data are expressed as mean \pm S.D., * denotes significant difference $(\mathrm{p}<0.05)$ versus PF group. $\mathrm{t}$-student non-paired.

\section{DISCUSSION}

This study shows that BJJ athletes differ significantly from kinanthropometric reference populations, and tend to exhibit the specific characteristics of body form and composition necessary for grappling combat sport competition. The main findings of this study were: 1) elite BJJ athletes have predominantly mesomorph somatotype, high relative muscle mass, low relative adipose mass, and 2) body composition, somatotype and the proportionality varied significantly in BJJ athletes of different fighting styles (i.e. PF vs. GF). To the best of the author's knowledge, this is the first scientific article that describes morphological characteristics of BBJ athletes according to fighting style, indicating that athletes with different anthropometric characteristics adopt different technical-tactical fighting styles.

Somatotype. The body form is assessed using somatotype; there are relationships between somatotype and the level of physical achievement in combat sports and wrestling (Yoon, 2002). Our results show that BJJ athletes had a balanced mesomorph somatotype, similar to that previously reported (Vidal Andreato et al., 2012a, 2012b; Del Vecchio, 2007). Interestingly, the BJJ athlete's somatotype was similar to that reported in judo (Claessens et al., 1987; Franchini et al., 2011) and Greco-Roman wrestling athletes (SterkowiczPrzybycien' et al., 2011).
Regarding the fighting style, the PF group was significantly less ectomorph and more mesomorph than the GF group. For the "pass fight" style, more "strength" positions are required during combats. This may help to explain the observed differences among PF and GF groups in the mesomorph component. On the other hand, for the "guard fight" style, more guard defensive actions are required during combats, implicating the generation of distance in relation with the opponent. In this case, a significant superior ectomorph (relative linearity) component may be a competitive advantage in athletes who utilize this fighting style. In this line, this also may explain the significant difference observed between PF and GF for height and HWR, where the latter presented significant higher values (Table I).

Body composition. Because there are many methods available for body composition estimation, it is difficult to standardize the measurements. This is the first study, which used the five-way fractionation model for tissue estimation in grappling combat sport athletes; therefore, it is difficult to compare with other studies.

The quantification of muscle mass in grappling athletes is of interest since specific training and nutrition control, are often undertaken by BJJ athletes to increase their muscle mass and minimize body fat mass (Santos et al.). In 
this study, the BJJ athletes had high absolute and relative muscle mass, suggesting that this is a necessary kinanthropometric characteristic for high-level BJJ competition.

When the adipose tissue mass value is estimated using five-way fractionation model, "high" values are obtained, compared to "percent body fat" of the chemical models (Holway \& Garavaglia, 2009), because this model estimates the anatomically defined "adipose tissue", as opposed to the more familiar chemically defined body fat (lipids), thus, adipose tissue is a larger entity comprising a lipid fraction (Martin et al., 1994). Five-way fractionation model has many advantages for the different tissues prediction (see material and methods). For example, the internal validity can be monitored using predicted structured body mass vs. actual body mass. In this study we reported a $0.01 \%$ difference between the real weight and model-based prediction, suggesting that this is a very useful model for this population. Utilizing other methods, previous studies have reported lower relative body fat in combat sport athletes, who presented body fat percentage below the population mean (Franchini et al., 2011).

Thus, the BJJ athletes in this study have low relative adipose tissue compared to those reported (using the same five-way fractionation model) in triathletes (Landers et al., 2000), rugby players (Holway \& Garavaglia), and volleyball players (Carvajal et al., 2012).

Proportionality. Relative to height, proportional muscle mass was very high in the BBJ athletes. In this way, the athletes show high girths z-score in the upper body segments, compared with lower body segments, suggesting a regional distribution of muscle mass. Interestingly, the forearm girths z-score have high values in all athletes; previously have been reported that handgrip actions may play an important role in BJJ match (Franchini et al., 2003). Moreover, in concordance with our muscle mass index (mesomorph, girth, z-score), $\mathrm{PF}$ group show a significant higher girth z-score value in the upper body segments and trunk vs. GF group.

PF athletes show a significantly higher phantom $\mathrm{Z}$ bone mass value and a significant superior mesomorph component than GF athletes. As muscle mass has been strongly correlated with bone density (Proctor et al., 2000), this may help explain the bone mass difference between groups. PF also had a significant lower muscle mass · bone mass ratio than GF. As a significant difference in the bone component was observed between PF and GF (i.e. significantly lower in the later), and no significant difference was evident between PF and GF for muscle mass, this may help explain why the ratio was superior in the GF group.
In sport-related human performance, physical structure is a necessary starting point for talent selection, the basis for the phenomenon known as morphological optimization, which aims to achieve optimal physical structure, body composition and somatotype for most efficient athletic performance in different sports (Lozovina \& Lozovina, 2008). However, in complex sports where techniques and tactics play a major role, the anthropometric profile not always properly discriminates higher and lower level athletes (Franchini et al., 2007). Our results show that different anthropometrical characteristics may be related to different fighting styles among BJJ. However, our results do not indicate a causal relationship; future studies must be conducted to clarify this point.

\section{CONCLUSIONS}

BJJ athletes differ significantly from reference populations in their physical form and composition, and tend to exhibit the specific characteristics of body shape and composition necessary for their sport. Body composition, somatotype and proportionality data in BJJ athletes seem to be similar to that reported in similar studies with combat sports athletes. The mean BJJ athlete shows a mesomorph somatotype component. However, the somatotype components can differ according to fighting style, where PF athletes exhibit significantly higher and lower mesomorph and ectomorph components, respectively vs. GF athletes. The current research expands the limited knowledge about morphological features of BJJ athletes of a high competitive level. The characterization of body form and its relation with fighting style can help in the selection of athletes and the preparation of appropriate training programs.

BÁEZ, E.; FRANCHINI, E.; RAMÍREZ-CAMPILLO, R.; CAÑAS-JAMETT, R.; HERRERA, T.; BURGOS-JARA, C. \& HENRÍQUEZ-OLGUÍN, C. Características antropométricas en atletas de Jiu Jitsu brasilero de alto nivel: Rol del estilo de lucha. Int. J. Morphol., 32(3):1043-1050, 2014.

RESUMEN: La eficiencia y efectividad del rendimiento humano en diferentes deportes depende en gran medida del tamaño, peso y proporción del físico del atleta. El objetivo de este estudio fue identificar las características morfológicas de atletas jiujitsu brasileros. La muestra consintió de 25 atletas varones altamente entrenados, quienes fueron clasificados de acuerdo a su estilo de lucha; guarderos (GF) vs pasadores (PF). Se evaluó en los atletas somatotipo, composición corporal y proporcionalidad. Para el grupo total de atletas el somatotipo fue $2,23 \pm 0,68,6,33 \pm 1,14$ y $1,75 \pm 0,78$ para el endomorfismo, mesomorfismo y ectomorfismo, respectivamente. Los porcentajes de tejido muscular y adiposo fueron $52,34 \pm 2,15 \%$ and $19,30 \pm 2,51 \%$, respectivamente. PF fueron significativamente las mesomorfos $(p<0,05)$ y menos 
ectomorfos $(\mathrm{p}<0,05)$ que GF. Además PF tuvieron una significativamente alto $\mathrm{Z}$ score para la masa ósea $(4,55 \pm 0,31$ vs. $4,77 \pm 0,56 ; \mathrm{p}<0,05)$, estatura $(1,71 \pm 0,06$ vs. $1,77 \pm 0,07 ; \mathrm{p}<0,05)$ y relación altura peso $(40,58 \pm 1.11$ vs. $41,84 \pm 1.22)$. Nuestros resultados muestran que las características morfológicas están relacionadas a diferentes estilos de lucha en atletas de BJJ.

PALABRAS CLAVE: Características antropométricas; Somatotipo; Jiu Jitsu; Estilo de lucha.

\section{REFERENCES}

Artioli, G.; Franchini, E.; Nicastro, H.; Sterkowicz, S.; Solis M. Y. \& Lancha, A. H. The need of a weight management control program in judo: a proposal based on the successful case of wrestling. J. Int. Soc. Sports Nutr., 7:15, 2010.

Boscolo Del Vecchio, F.; Bianchi, S.; Masashi Hirata, S. \& Trainá Chacon-Mikahi, M. P. Análise morfo-funcional de praticantes de brazilian jiu-jitsu e estudo da temporalidade e da quantificação das ações motoras na modalidade. Mov. Percepção, 7(10):263-81, 2007.

Carvajal, W.; Betancourt, H.; León, S.; Deturnel, Y.; Martínez, M.; Echevarría, I.; Castillo, M. E. \& Serviat, N. Kinanthropometric profile of Cuban women Olympic volleyball champions. MEDICC Rev., 14(2):16-22, 2012.

Claessens, A.; Beunen, G.; Wellens, R. \& Geldof, G. Somatotype and body structure of world top judoists. J. Sports Med. Phys. Fitness, 27(1):105-13, 1987.

Franchini, E.; Brito, C. J. \& Artoli, G. G. Weight loss in combat sports: physiological, psychological and performance effects. J. Int. Soc. Sports Nutr., 9(1):52, 2012.

Franchini, E.; Del Vecchio, F. B.; Matsushigue, K. A. \& Artioli, G. G. Physiological profiles of elite judo athletes. Sports Med., 41(2):147-66, 2011.

Franchini, E.; Nunes, A. V.; Moraes, J. M. \& Del Vecchio, F. B. Physical fitness and anthropometrical profile of the Brazilian male judo team. J. Physiol. Anthropol., 26(2):59-67, 2007.

Franchini, E.; Takito, M. Y. \& Campos Pereira, J. N. Freqüência cardíaca e força de preensão manual durante a luta de jiu-jitsu. Buenos Aires, Efdeportes.com, 2003. Disponible en: http:// www.efdeportes.com/efd65/jiujitsu.htm

Franchini, E.; Takito, M. Y.; Kiss, M. A. P. D. M. \& Sterkowic, S. Physical fitness and anthropometric differences between elite and non-elite judo players. Biol. Sport, 22(4):315-28, 2005.

Gualdi-Russo, E. \& Graziani, I. Anthropometric somatotype of Italian sport participants. J. Sports Med. Phys. Fitness, 33(3):282-91, 1993.
Henríquez, O. C.; Báez, S. M.; Von Oetinger, A.; Cañas, J. R. \& Ramírez, C. R. Autonomic control of heart rate after exercise in trained wrestlers. Biol. Sport, 30(2):111-5, 2013.

Holway, F. E. \& Garavaglia, R. Kinanthropometry of Group I rugby players in Buenos Aires, Argentina. J. Sports Sci., 27(11):1211-20, 2009.

Iide, K.; Imamura, H.; Yoshimura, Y.; Yamashita, A.; Miyahara, K.; Miyamoto, N. \& Moriwaki, C. Physiological responses of simulated karate sparring matches in young men and boys. J. Strength Cond. Res., 22(3):839-44, 2008.

Iwai, K.; Okada, T.; Nakazato, K.; Fujimoto, H.; Yamamoto, Y. \& Nakajima, H. Sport-specific characteristics of trunk muscles in collegiate wrestlers and judokas. J. Strength Cond. Res., 122(2):350-8, 2008.

Kerr, D. A. An anthropometric method for fractionation of skin, adipose, bone, muscle and residual tissue masses, in males and females age 6 to 77 years. Master's Thesis. Vancouver, Simon Fraser University, 1988.

Landers, G. J.; Blanksby, B. A.; Ackland, T. R. \& Smith, D. Morphology and performance of world championship triathletes. Ann. Hum. Biol., 27(4):387-400, 2000.

Lozovina, V. \& Lozovina, M. Morphological optimisation, overlap zones and secular trend in selection pressures. Acta Kinesiologica, 2(1):35-41, 2008.

Martin, A. D.; Daniel, M. Z.; Drinkwater, D. T. \& Clarys, J. P. Adipose tissue density, estimated adipose lipid fraction and whole body adiposity in male cadavers. Int. J. Obes. Relat. Metab. Disord., 18(2):79-83, 1994.

Moreira, A.; Franchini, E.; de Freitas, C. G.; Schultz de Arruda, A. F.; de Moura, N. R.; Costa, E. C., \& Aoki, M. S. Salivary cortisol and immunoglobulin A responses to simulated and official JiuJitsu matches. J. Strength Cond. Res., 26(8):2185-91, 2012.

Proctor, D. N.; Melton, L. J.; Khosla, S.; Crowson, C. S.; O'Connor, M. K. \& Riggs, B. L. Relative influence of physical activity, muscle mass and strength on bone density. Osteoporos. Int., 11(11):944-52, 2000.

Ross, W. D. \& Marfell-Jones, M. J. Kinanthropometry. In: MacDougall, J. D.; Wenger, H. A. \& Green, H. J. (Eds.). Physiological testing of the high-performance athlete. Champaign, Human Kinetics Books, 1991.

Sterkowicz-Przybycien, K. L.; Sterkowicz, S. \& Zarów, R. T. Somatotype, body composition and proportionality in Polish top greco-roman wrestlers. J. Hum. Kinet., 28:141-54, 2011.

Santos, W.; Brito, C.; Júnior, E.; Valido, C.; Mendes, E.; Nunes, M. \& Franchini, E. Cryotherapy post-training reduces muscle damage markers in jiu-jitsu fighters. J. Hum. Sport Exerc., 7(3):629-38, 2012. 
BÁEZ, E.; FRANCHINI, E.; RAMÍREZ-CAMPILLO, R.; CAÑAS-JAMETT, R.; HERRERA, T.; BURGOS-JARA, C. \& HENRÍQUEZ-OLGUÍN, C. Anthropometric characteristics of topclass Brazilian Jiu Jitsu athletes: Role of fighting style. Int. J. Morphol., 32(3):1043-1050, 2014.

Tsang, B.; Chan, C. K. \& Taylor, G. Kinanthropometry study of the physique of disciplined personnel. Int. J. Cloth. Sci. Technol., 12(2):144-60, 2000.

Vidal Andreato, L.; Franzói de Moraes, S. M.; Lopes de Moraes Gomes, T.; Del Conti Esteves, J. V.; Vidal Andreato, T. \& Franchini, E. Estimated aerobic power, muscular strength and flexibility in elite Brazilian Jiu-Jitsu athletes. Sci. Sports, 26(6):329-37, 2011.

Vidal Andreato, L.; Franchini, E.; Franzói de Moraes, S. M.; Del Conti Esteves, J. V.; Pastório, J. J.; Vidal Andreato, T.; Moraes Gomes, T. L. \& Lopes Vieira, J. L. Morphological profile of Brazilian Jiu-Jitsu elite athletes. Rev. Bras. Med. Esporte, 18(1):46-50, 2012a.

Vidal Andreato, L.; Franzói de Moraes, S. M.; Del Conti Esteves, J. V.; Araújo Pereira, R.; Lopes de Moraes Gomes, T.; Vidal Andreato, T. \& Franchini, E. Physiological responses and rate of perceived exertion in brazilian jiu-jitsu athletes. Kinesiology, 44(2):173-81, $2012 b$.

Yoon, J. Physiological profiles of elite senior wrestlers. Sports Med., 32(4):225-33, 2002.
Correspondence to:

Carlos Henríquez-Olguín

Laboratory of Exercise Science, MEDS Clinic

Isabel La Católica 3740

Las Condes, Santiago

CHILE

Email: carlos.henriquez@meds.cl

Received: 11-09-2013

Accepted: 30-05-2014 